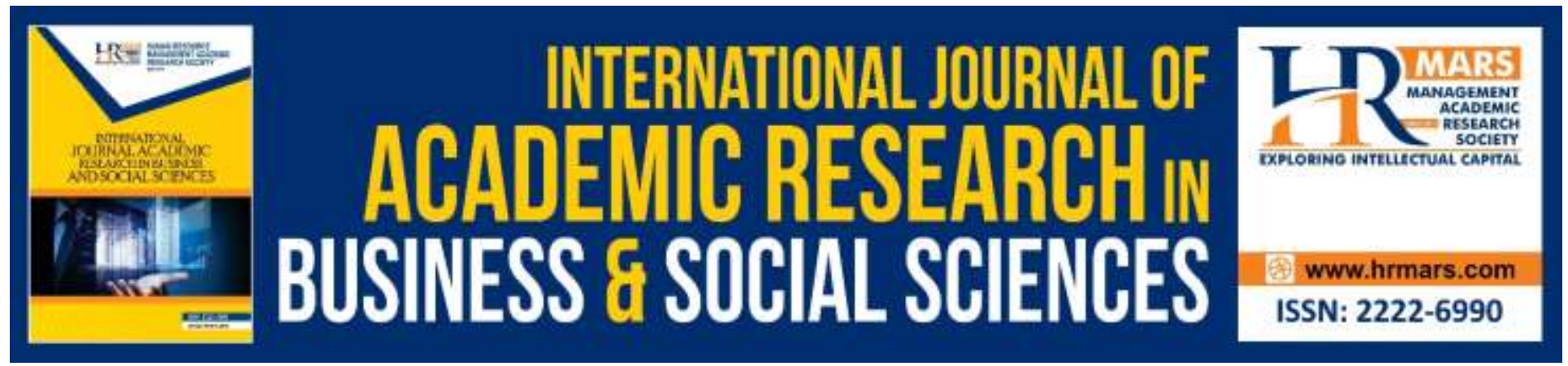

\title{
Relationship between Performance and Intellectual Capital on Government Sector Organization in Malaysian
}

\author{
Intan Safura Abdul Rahman, Shahimi Mohtar
}

To Link this Article: http://dx.doi.org/10.6007/IJARBSS/v9-i11/6624

DOI: 10.6007/IJARBSS/v9-i11/6624

Received: 10 October 2019, Revised: 30 October 2019, Accepted: 03 November 2019

Published Online: 13 November 2019

In-Text Citation: (Rahman \& Mohtar, 2019)

To Cite this Article: Rahman, I. S. A., Mohtar, S. (2019). Relationship between Performance and Intellectual Capital on Government Sector Organization in Malaysian. International Journal of Academic Research in Business and Social Sciences, 9(11), 1041-1049.

\section{Copyright: (C) 2019 The Author(s)}

Published by Human Resource Management Academic Research Society (www.hrmars.com)

This article is published under the Creative Commons Attribution (CC BY 4.0) license. Anyone may reproduce, distribute, translate and create derivative works of this article (for both commercial and non-commercial purposes), subject to full attribution to the original publication and authors. The full terms of this license may be seen at: http://creativecommons.org/licences/by/4.0/legalcode

Vol. 9, No. 11, 2019, Pg. 1041 - 1049

Full Terms \& Conditions of access and use can be found at http://hrmars.com/index.php/pages/detail/publication-ethics 


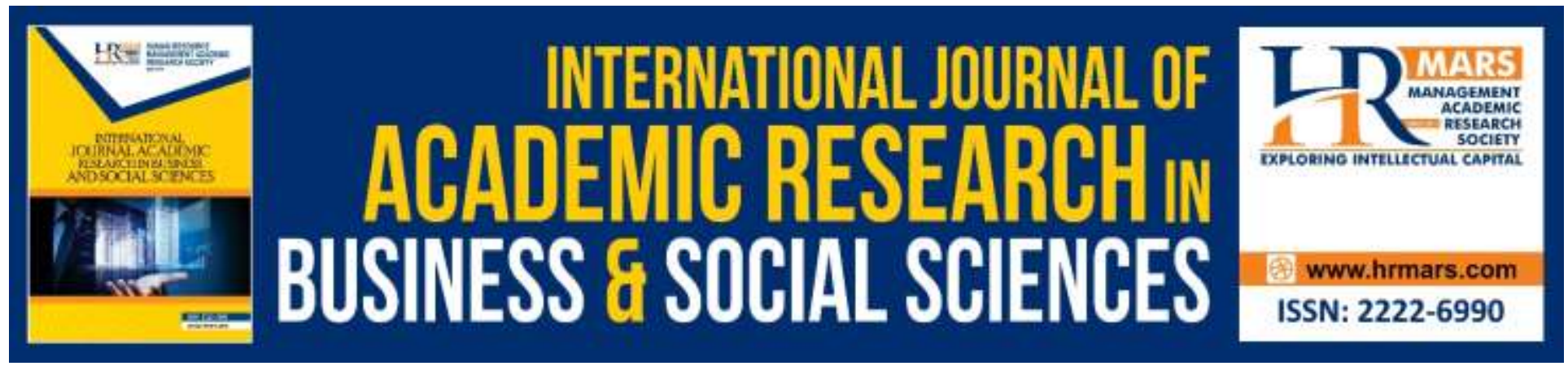

\title{
Relationship between Performance and Intellectual Capital on Government Sector Organization in Malaysian.
}

\author{
Intan Safura Abdul Rahman, Shahimi Mohtar \\ School of Technology Management and Logistic, College of Business, Universiti Utara Malaysia, \\ Kedah, Malaysia.
}

\section{Abstract}

Government sector performance is frequently associated with a high level of intellectual capital and innovation capability. Hence the intellectual capital and innovation capability as a key success factor in an increasingly competitive, global economy has the ground work for researcher to explore new practices of management. Otherwise, an innovation is depending heavily on knowledge. The intellectual capital is defined as combination of human, structural and relation capital that creates value and consequently determines the performance of a firm whilst innovation capability refer to the ability of a firm to transform an idea into a something new which carries an economic value. Intellectual capital is a resources that is embedded in the actions and capabilities of the individuals that operate in an organization.

Keywords: Government Sector Performance, Intellectual Capital, Innovation Capability.

\section{Introduction}

Measuring achievements is a common practice by all organizations (Paker, 2000). According to B.W Associates (1994) defines performance as a functional way or quality where it implies that performance management concerns the way or quality of management. Kaydos (1991) defines achievement as if something was done with what was supposed to be done. Basically, there are two basic objectives of performance namely accountability and improvement (Foster, 2001).

\section{Performance Measurement}

Performance measurement is an important for achieving and maintaining the high level of productivity and quality (Sinclair \& Zairi, 1995) which provides a link between strategy and action (Dixon et al, 1990) for good management control and planning for development and 
motivation an organization (Nanni et al., 1990, Roberts, 1994). Through performance measurements, organizations can have answers to what happens, why it happens, and either it will continue or what we will do (Norehan, 2002).

Performance measurement involves collecting, analyzing and reporting information systematically to management (Mokhtar, 2002) and is a process of measuring past action (Neely, 1998). In way of good performance measurement system, it must have operating links to strategic objectives integrating financial and non-financial information which should focus on customers (Mokhtar, 2002). Other than that, Lynch and Cross (1991), dimension of performance also must beware and focus either external or internal, such as corporate vision, financial, market, customer satisfaction, flexibility, productivity, services quality, timeliness, efficiency and cost of resources use and innovation (Figure 1).

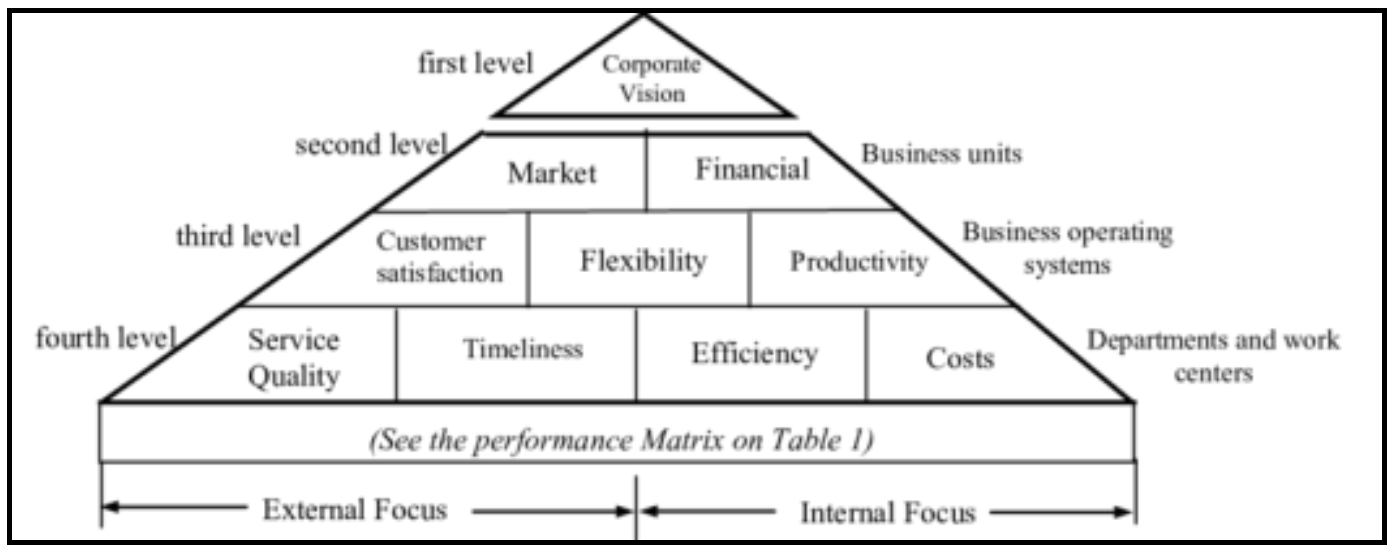

Figure 1: The Performance Pyramid

\section{Adopted source by Lynch and Cross, 1991}

However, many different government departments contribute to the overall services provided to citizens. Otherwise, governments organized and managed by department or agency judiciary, law enforcement, social services, treasury, transport, health, environment, home and building affair and others (figure2). But the in government sector organization, performance measurement required is focused on service provided to citizens.

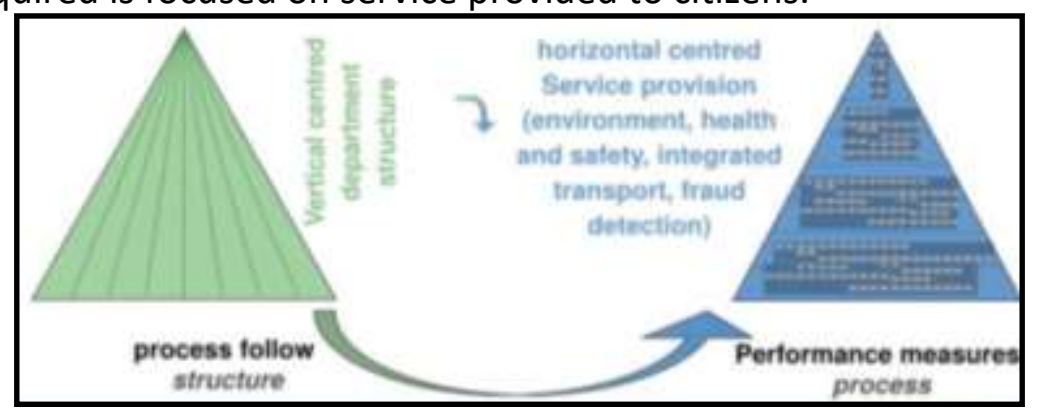

Figure 2: Structure and Process Government sector 
In generally, an organizations measure performance for various reasons such as to identify their success, identify their achievement, understand their operation process, identify where problems and improvements are needed, and to ensure that decisions are based on facts that are not based on emotion or intuition (Paker, 2000).

\section{Intellectual Capital}

Intellectual capital is considered one of the most crucial intangible assets in today's knowledge-based economy and is an element in the value creation of an organization (Chen et al., 2005; Waseem, 2018). Intellectual capital also has been identified as a major sources and organizational achievement and value creation (Itami, 1991; Teece, 1998, May, 2000). Narvar and Slater (1990) find that the relationship and organizational capital market (ROA) orientation is very closely related and Jaworski and Kohli (1993) claim that market orientation is an important determinant in its study of 222 business organization units United States of America. Intellectual capital, regarded as the most important intangible asset within the company, had a significant impact on the success of this valuable organization through understanding, developing and managing the company's non-significant assets (Nonaka \& Takeuchi, 1995).

Youndt (1998) as empirically demonstrates the relationship between an intellectual capital and achievement;

i. Human Capital has a positive effect on sales growth but is not related to financial returns.

ii. Relationship capital has a negative relationship with sales growth and does not show significant relationship with financial returns.

iii. Intangible capital structure relates to sales growth but positively related to financial returns.

iv. Human capital is not much associated with the reduced organizational costs but it is closely related to the increase in customer benefits.

v. Relationship capital shows no significant relationship to increase benefits but is significantly associated with reducing organizational costs.

vi. Capital structure is intangible when it is associated with a reduction in organizational costs, but is positively related to increased interest to customers.

Based on Bontis (1998), relationship between the types of intellectual capital and organizational achievement;

i. Human capital is related to capital structure

ii. Human capital has significance relating to transportation capital

iii. Capital structure is related to organizational performance

iv. Relationship capital is related to organizational performance

However, Bontis (2001), relationship between the types of intellectual capital and organizational achievement of Malaysia industries such as; 
i. Human capital has a lot of significance in relationship capital for services industry and non-service industries.

ii. Human capital has significant in relation to structural capital for non-services industries.

iii. Human capital is not significant in relation to structural capital for the services industry.

iv. Relationship capital has significant relating to structural capital for the services industry and non-services industries.

v. Structural capital is related to organizational performance for the services industry and non-service industries.

Walker (2001), empirically said relationship between human capital and performance measurements;

i. The value of human capital has significant relationship with the performance measurement of the firm's human capital market value in the knowledge-based industry.

ii. Human capital value has a significant relationship with the measurement of organizational performance in terms of market value of human capital in a high knowledge-based industry

iii. The value of human capital does not relate much to measure productivity, profitability or market performance either in low knowledge based industries or high knowledge-based industry.

Shook (2002), shows the relationship between analyst and investor attitudes towards intellectual capital;

i. The value of intellectual capital is an investment decision factor which has at least a comparable value with the value of traditional financial and physical assets.

ii. The intellectual capital value is a determination for the organization's growth, development and evaluation base on analyst or investment.

A case study of Shell company, they had confirmed the impact of intangible assets such as employee satisfaction, organizational culture, environment and social responsibility affecting their corporate strategy and financial performance (Marr et.al, 2002,2003; Karam and Sushila, 2012).

In addition to intellectual capital, knowledge that has strong relationships with intellectual capital also form the basis company business performance (Marr et.al.,2002; Karam and Sushila, 2012) is a strategic resource for companies to develop their competitive capabilities (Devenport and Prusak, 1998) and creation is closely related to business performance (Grant, 1996; Bontis, 1999). However, the most knowledgeable firs do not always be the most profitable. Knowledgeable only leads to superior performance if the industry's characteristics allow the 
knowledgeable company to adjust profit from new ideas (Bierly and Daly,2002; Fakhraddin,Hossein, Marzieh, 2013).

Based on the above discussion, there are proposed construct under Intellectual Capital

(figure 3)

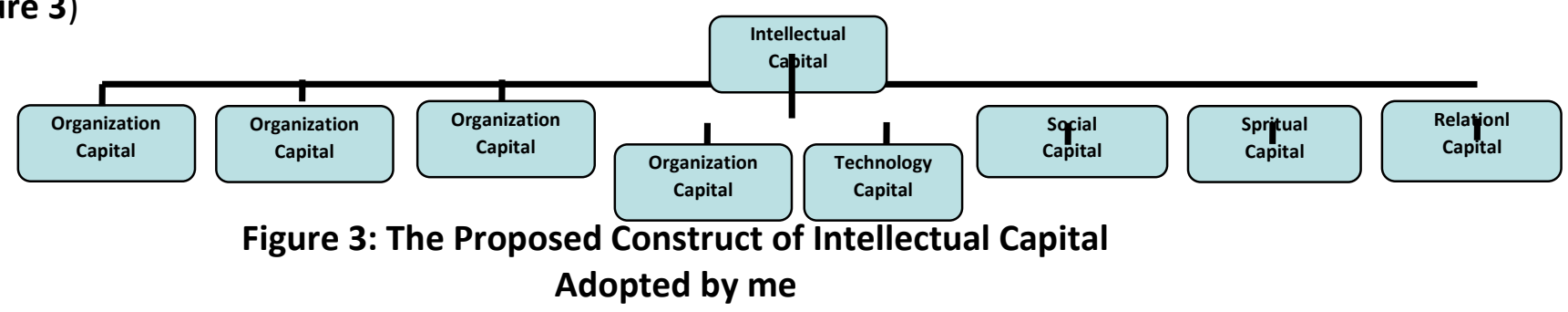

\section{Innovation Capability}

According to Kim (1997), the ability of innovation is the ability to create new and useful knowledge based on previous knowledge. Innovation capability also performs the role of value addition for organizational success, so the companies with product and process innovation and exporting capability can achieve substantial performance (Love \& Roper, 2015; Vila \& Kuster, 2007; Wassem, 2018) Innovation capabilities are proven comprehensive based on organizational features that facilitate and support strategic innovation. In addition, innovation capabilities are defined as higher order consolidation to ensure that every member of the organization has the capability to shape and manage organizational capabilities in a different way that existing resources as well as to ensure that innovation activities are carried out successfully. Raymond et al. (2013) asserted that innovation capability leads to organizational growth and productivity.

It means, the ability of innovation means creation. Therefore, inventions are the result of new ideas, processes or products. Meanwhile, new inventions also refer to new products, while innovation is a new value (Szmtkowski, 2005). According to West \& Farr (1990), innovation can be defined as an introduction, application in the role, group, idea organization, and new processes, products or procedures associated with acceptance designed to provide tangible benefits to individuals, group, organizations and communities. Walker, Jeanes \& Rowlands (2002) make a difference between product innovations and processes. Product innovations are defined as new products or services, while process innovating is defined as new elements introduced into organizational products, service operations and processes.

\section{Conclusion}

Consequently, based on the above discussion, intellectual capital and innovation capability most import to organization to improve reputation, services quality delivery, effectiveness and efficiency in performance. Performance measurement is the concept to the government sector to improve organization performance. So that there are proposed framework that suggested (Figure 4) 


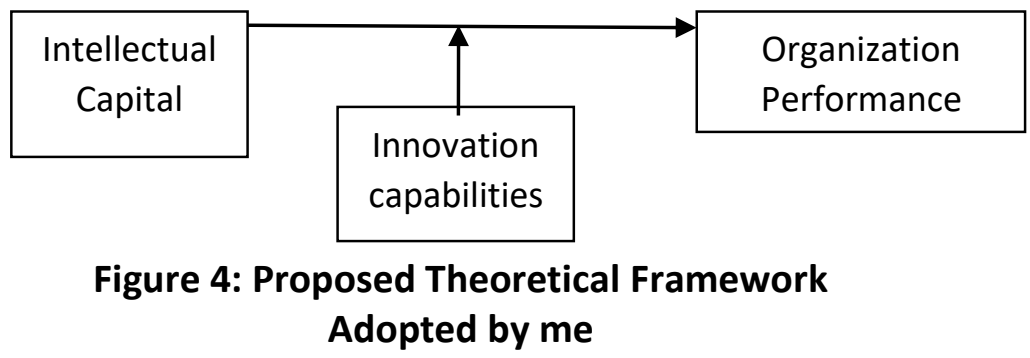

- In this study, a theoretical framework is attested by investigating the effects of intellectual capital (human, customer, structural, organization, technology, social, spiritual, relation) with innovation capability and the organizational performance of government sector in Malaysian. Other than that, organization performance in this study discuss the process of innovation capability that can be improve organizational, process, and services to achieve organizational performance base on organization objective. Despite its contribution, this study has some limitations. First, this study focused only on the government sector in Malaysian. However, in organization performance, future research, can focus on timeliness, responsiveness services accessibility and services coverage. Second, the nature of this study is cross sectional and the questionnaire are collected in Lembah Klang areas in a specific point in time.

\section{References}

\section{Journal Article}

Neely, A. (1998). Implementing performance measurement systems: a literature review. International Journal Business Performance Management, Vol.5, No. 1.

Associates, B. W. (1994). The Contributions of Total Quality Management to A Theory of Work Performance. Academy of Management Review, Vol.19, No.3

Bierly, P., \& Daly, P. (2002). Aligning human resource management practices and knowledge strategies: A theoretical framework. In C. W. Choo, \& N. Bontis (Eds), the startegic management of intellectual capital and organizational knowledge. Oxford University Press

Bernard, J., Jaworski and Ajay, K. K. (1993). Market orientation: Antecedents and consequences. Journal of Marketing Vol. 57 (July 1993), 53-70

Bontis, N. (1998). Intellectual Capital: An Exploratory Study that Develops measure and Models. Journal of Intellectual Capital, Vol.36 (2)

Bontis, N. (2001), 'Assessing knowledge assets: a review of the models used to measure intellectual capital', International Journal of Management Reviews, 3(1), pp.41-60

Chen, Ming-Chin, Cheng, S. -J., \& Hwang, Y. (2005). An empirical investigation of the relationship between intellectual capital and firms' market value and financial performance. Journal of Intellectual Capital, 6(2), 159-176. 
INTERNATIONAL JOURNAL OF ACADEMIC RESEARCH IN BUSINESS AND SOCIAL SCIENCES

Vol. 9, No. 11, November, 2019, E-ISSN: 2222-6990 @ 2019 HRMARS

Sinclair, D., \& Zairi, M. (1995), Effective process management through performance measurement. Business process Re-engineering \& management Journal. Vol.1 No.1, pp.588.

David, J., Teece, G. P., Shuen, A. (1998), Dynamic capabilities and strategic management. Strategic Management Journal

Maroofi, F., Nayebi, H., and Dehghani, M. (2013). Strategic Knowledge Management, Innovation and Performance. International of Research in Social Science. Vol.3, No.3, Nov 2013

Grant, R. (1996). Toward a knowledge-based theory of the firm. Strategic Management Journal, 17 (7), 109-122.

James, G., Combs, T., Crook, R., and Christopher, L. S. (2002), The dimensionality of organizational performance and its implications for strategic management research, research methodology in strategy and management.

Pal, K., Soriya, S. (2012). Intellectual capital performance of Indian pharmaceutical and textile industry. Journal of intellectual capital, Vol. 13 Issue: 1 pp.120-137

Kim, W., and Engeda, A. (1997), Comparison of pressure recovery and overall performance of different diffusers for Centrifugal Compressor, In FEDSM97-3029 Fluids Engineering Division Summer Meeting, ASME.

Lovelock, C. H., Patterson, P. G., and Walker, R. H. (2001). Services Marketing: An Asia-Pacific Perspective, $2^{\text {nd }}$ Ed. Australia: Prentice Hall.

Love, J. H., \& Roper, S. (2015). SME innovation, exporting and growth: A review of existing evidence. International Small Business Journal, 33(1), 28-48.

Lynch, R. L., and Cross, K. F. (1991). Measure up: Yardsticks for Continuous Improvement. Blackwell. USA.

Narver, J. C., and Slater, S. F. (1990). The effect of a market orientation on business profitability. Journal of Marketing, 54, 20-35.

Nonaka, I., and Takeuchi. (1995). The knowledge creating company: How Japanese Companies Create the Dynamics of Innovation. Oxford University Press. New York.

Paker. (2000). Evaluating performance and providing feedback to employees. Journal performance Appraisal.

Steward, T. A. (1997). Intellectual capital: the new wealth of organization. New York: Doubleday.

Marr, B., Gray, D., and Neely, A. (2003). "Why do firms measure their intellectual capital?', Journal of Intellectual Capital, Vol. 4 No. 4, pp. 441-664

Thomas, H. D., and Prusak, L. (1998). Working knowledge: How organizations manage what they know. Ubiquity, an ACM IT Magazine and Form.

Vila, N., \& Kuster, I. (2007). The importance of innovation in international textile firms. European journal of marketing. 41 (1/2), 17-36.

Walker, Jeanes, \& Rowland. (2002). Managing Public Services Innovation: The experience of English housing associations. Journal of housing and the built environment, volume 17(2)

Barkat, W., Beh, L. S., Ahmed, A., and Ahmed, R. (2018). Impact of intellectual capital on innovation capability and organizational performance: An empirical investigation. Serbian Journal of Management 13(2), pp 365-379. 
West, M. A., and Farr, J. L. (1990). Innovation and creativity at work: Psychological and organizational strategies (pp.3-13). Chi Chester, England: Wiley.

West, M. A. \& Anderson, N. R. (1996). The innovation in top management temas. Journal of Applied Psychology,6, 680-693.

Youndt, M. A. (1998). Human resource management systems, intellectual capital and organizational performance. Unpublished PhD thesis, Pennsylvania State University.

\section{Book}

Mohammad, I. J., \& Alam, S. S. M. (1991). APA guide to preparing manuscripts for journal publication. Washington, DC: American Psychological Association.

Kaydos, W. (1991). Measuring, managing and maximizing performance. Productivity Press.

Zagreb. (2007). Intellectual Capital, Handbook of IC Management in Companies. Croatia, Intellectual Capital Center Croatia. 